\title{
Hard Tissue Laser Applications in Pediatric Dentistry
}

\section{Mahkameh Mirkarimi ${ }^{1, *}$}

${ }^{1}$ Pediatric Dentistry Department, Shahid Beheshti University of Medical Sciences, Tehran, IR Iran

"Corresponding author: Mahkameh Mirkarimi, Shahid Beheshti University of Medical Sciences, School of Dentistry, Velenjak Ave, Daneshjou Blv, Tehran, IR Iran. Tel: +98-9122039859, +98-2188663752, E-mail: mirkarimi200@hotmail.com

Received 2017 August 20; Revised 2018 January 04; Accepted 2018 January 24.

Keywords: Laser Therapy, Pediatric Dentistry, Child

\section{Dear Editor,}

Dental caries as the most prevalent infectious disease may affect the child population's health, growth and development $(1,2)$. Accordingly, appropriate dental treatments are required to restore oral and subsequently general health.

Most child patients cope with in-office routine dental treatments by receiving communicative behavior management techniques. However, there are some indications for general anesthesia where in-office services cannot be conducted $(3,4)$. On the other hand, there has always been an attempt to use the technology of the day in pediatric dentistry. One relevant advanced modality is laser therapy, which can be suggested as an appropriate alternative of conventional dentistry (5).

Laser therapy is well known as acceptable by child population due to its minimally invasive nature $(6,7)$. By using laser, minimum amount of sound hard tissue is removed, allows for conservative tooth preparation and low risk of pulp exposure (8). There are several applications of various types of laser in pediatric dentistry (5). Laser is a useful tool to diagnose and monitor carious lesions $(7,9,10)$. In the field of caries prevention, laser is used for the increasing of enamel surface resistance against acid attack, and for the conditioning of tooth surface for sealant placement and preventive resin restorations $(5,7)$. Another hard tissue application is for tooth restoration and pulp therapies (5).

Benefits of laser therapy in child dental services are as follow: no or minimal amount of anesthetic solution needed $(7,8)$, no drilling and the absence of handpiece vibration, noise and pressure during caries removal $(5,8)$, no consequences such as intraoperative and postoperative soft tissue numbness and biting, minimizing the dental fear and apprehension in child subject (7). The other benefit is its bactericidal effect especially favorable in root canal preparation (7). In addition, one benefit that cannot be overemphasized is the possible performing multiple sextant therapies in each session and reducing the need for operation under general anesthesia.

All of these, promote children's dental behavior, save their cooperation capacity and at the same time make the procedure less traumatic, more pleasant, and able to alleviate patient discomfort and also make the child safe. Familiarity with various types of laser and their physical properties along with applying safety considerations are prerequisites to use this micro-dentistry modality. Finally this fact should be mentioned that behavior management techniques are again considered as integral part of laser pediatric dentistry, as used in conventional child dental services.

\section{References}

1. Monse B, Heinrich-Weltzien R, Benzian H, Holmgren C, van Palenstein Helderman W. PUFA-an index of clinical consequences of untreated dental caries. Community Dent Oral Epidemiol. 2010;38(1):77-82. doi: 10.1111/j.1600-0528.2009.00514.x. [PubMed: 20002630].

2. Ramazani N, Rezaei S. Evaluation of the prevalence of clinical consequences of untreated dental caries using PUFA/pufa index in a group of Iranian children. Iran J Pediatr. 2017;27(1).

3. Ramazani N. Different Aspects of General Anesthesia in Pediatric Dentistry: A Review. Iran J Pediatr. 2016;6(2). e2613. doi: 10.5812/ijp.2613.

4. Shin B, Yoo S, Kim J, Kim S, Kim J. A survey of dental treatment under general anesthesia in a Korean university hospital pediatric dental clinic. J Dent Anesth Pain Med. 2016;16(3):203-8. doi: 10.17245/jdapm.2016.16.3.203. [PubMed: 28884154].

5. Olivi G, Caprioglio C, Olivi M, Genovese MD. Paediatric laser dentistry. Part 2: Hard tissue laser applications. Eur J Paediatr Dent. 2017;18(2):163-6. doi:10.23804/ejpd.2017.18.02.14. [PubMed: 28598190].

6. Hanna R, Parker S. The advantages of carbon dioxide laser applications in paediatric oral surgery. A prospective cohort study. Lasers Med Sci. 2016;31(8):1527-36. doi: 10.1007/s10103-016-1978-8. [PubMed: 27457766].

7. Ramazani N, Ahmadi R, Daryaeian M. Oral and dental laser treatments for children: applications, advantages and considerations. J Lasers Med Sci. 2012;3(1):44.

8. Valerio RA, Borsatto MC, Serra MC, Polizeli SA, Nemezio MA, Galo R, et al. Caries removal in deciduous teeth using an Er:YAG laser: a random- 
ized split-mouth clinical trial. Clin Oral Investig. 2016;20(1):65-73. doi: 10.1007/s00784-015-1470-z. [PubMed: 25877234].

9. Bussaneli DG, Restrepo M, Boldieri T, Albertoni TH, Santos-Pinto L, Cordeiro RC. Proximal caries lesion detection in primary teeth: does this justify the association of diagnostic methods? Lasers Med Sci. 2015;30(9):2239-44. doi: 10.1007/s10103-015-1798-2. [PubMed:
26286856].

10. Laitala ML, Jaanti E, Vähänikkilä $H$, Määttä T, Heikka H, Hausen H, et al. Laser fluorescence in monitoring the influence of targeted tooth brushing on remineralization of initial caries lesions on newly erupted molar teeth - RCT. Int J Dent Hygiene. 2017;15(4):e78-84. doi: 10.1111/idh.12205. 